\title{
SIMULATING OF FUTURE CLIMATE CONDITIONS ON THE EFFECT OF IRRIGATION ON SUGARCANE YIELD IN SOUTHERN BRAZIL
}

\author{
Eduardo de Castro Mattos ${ }^{1}$, Thaís Cattarine Henriques Tomé ${ }^{1}$, Rafael Braghieri Menillo ${ }^{1}$, Fábio \\ Ricardo Marin ${ }^{1}$ \\ ${ }^{1}$ Escola Superior de Agricultura "Luiz de Queiroz" - ESALQ/USP, São Paulo State, Brazil \\ E-mail: eduardo.castro.mattos@usp.br, thaischt@usp.br, rafael.menillo@usp.br, fabio.marin@usp.br
}

\begin{abstract}
The objective of this study was to evaluate the technical and economic feasibility of installing central pivot irrigation systems in current days (Scenario A) and in two future scenarios, one with a $10 \%$ increase in rainfall (Scenario B1) and the other with $10 \%$ reduction in rainfall (Scenario B2). For both future scenarios, an increase of $2^{\circ} \mathrm{C}$ in the global temperature and the concentration of atmospheric carbon dioxide $\left(\mathrm{CO}_{2}\right)$ increasing to $528 \mathrm{ppm}$ (parts per million) were considered. For the study, the recommendation for an area of clayey soil and with the sugarcane cycle was evaluated on three different planting dates: May 15, August 15 and November 15. The DSSAT/CANEGRO model was used, and under the current conditions, the simulations indicated greater yield for planting in May, both for rainfed and irrigated. For scenario B1, there was an increase in yield of $22 \%$ for rainfed and $33 \%$ for irrigated. In addition, irrigation provided yield gains in the two future scenarios of $13 \%$ and $14 \%$ for B1 and B2, respectively. Based on the results obtained, central pivot irrigation proved economically viable in the simulated climatic conditions. Therefore, the increase in sugarcane production provided by irrigation in agronomic management was sufficient to make investment in the region in question feasible. It is suggested to repeat the study in other regions, since the existing synergy between the factors that define agricultural yield can change the decision making about the implantation of irrigation systems in the production environment.
\end{abstract}

Keywords: Climate change, Saccharum spp., irrigation, crop modeling, DSSAT 


\section{SIMULAÇÃO DAS CONDIÇÕES CLIMÁTICAS FUTURAS SOBRE O EFEITO DA IRRIGAÇÃO NA PRODUTIVIDADE DA CANA-DE-AÇÚCAR NO SUDESTE BRASILEIRO}

\section{RESUMO}

O objetivo deste estudo foi avaliar a viabilidade técnico-econômica da instalação de sistemas de irrigação do tipo pivô-central em dias atuais (Cenário A) e em dois cenários futuros, um com aumento em 10\% na pluviosidade (Cenário B1) e outro com redução em 10\% na pluviosidade (Cenário B2). Para ambos os cenários futuros, foi considerado um aumento de $2{ }^{\circ} \mathrm{C}$ na temperatura global e a concentração de dióxido de carbono $\left(\mathrm{CO}_{2}\right)$ atmosférico aumentando para 528 ppm (partes por milhão). Para o estudo, avaliou-se a recomendação para uma área de solo argiloso e com o ciclo da cana-de-açúcar em três diferentes datas de plantio: 15 de maio, 15 de agosto e 15 de novembro. Utilizou-se o modelo DSSAT/CANEGRO e, nas condições atuais, as simulações indicaram maior produtividade para o plantio em maio, tanto para sequeiro quanto para irrigado. Para o cenário B1, observou-se aumento na produtividade de $22 \%$ para sequeiro e $33 \%$ para irrigado. Além disso, a irrigação proporcionou ganhos de produtividade nos dois cenários futuros de $13 \%$ e $14 \%$ para B1 e B2, respectivamente. Baseando-se nos resultados obtidos, a irrigação por pivô central mostrou-se viável do ponto de vista econômico nas condições climáticas simuladas. Portanto, o incremento na produção de cana-de-açúcar proporcionado pela irrigação no manejo agronômico foi suficiente para viabilizar o investimento na região em questão. Sugere-se repetir o estudo em outras regiões, pois a sinergia existente entre os fatores que definem a produtividade agrícola pode alterar a tomada de decisão sobre implantação de sistemas de irrigação no ambiente de produção.

Palavras-chave: Mudanças climáticas, Saccharum spp., irrigação, modelagem, DSSAT

\section{INTRODUCTION}

Currently, there is much debate on the global climate issue and, in 2015, the 21st Conference of the Parts (COP21) took place, in which the "Paris Agreement" was approved, whose objective is to limit the Earth's warming to $2^{\circ} \mathrm{C}$ (EPE, 2016). Among the various strategies discussed, the replacement of fossil fuels by biofuels appears as the second most cited strategy, mainly in middle-income countries (FGV, 2017). 
Faced with this future scenario, Brazil guaranteed its engagement in the proposal by creating the National Biofuels Program (Renovabio), which encourages sustainable production and the consumption of biofuels (FGV, 2017). The Program guaranteed predictability for the entire sugar and energy chain. With this, it is expected that there will be an increase in investments involving the sector and an increase in the supply and demand for hydrated and anhydrous ethanol (ethanol mixed with gasoline). Both are the main biofuels in terms of production and national consumption, in addition to having excellent technical and economic performance. Consequently, there may be an impact on the demand for sugarcane, the main raw material used in Brazil to produce ethanol. Therefore, the sector should work to increase the sugarcane agricultural yield (MARIN, 2016).

One of the future challenges that sugarcane and other crops will have will be the effect of climate change on agricultural production. The supposed increases in temperature and in the concentration of atmospheric $\mathrm{CO}_{2}$ may have a negative or positive impact, depending on the physiological characteristics of the crop, the production environment and the management adopted.

At the current juncture, there are several technological alternatives that allow the design of future agricultural scenarios. Among the most used are agricultural models, mathematical analogs obtained to represent real systems (AGUIRRE, 2000). Process-based models use input data with meteorological variables, soil, plant nutritional status and management adopted under present scenarios and, with data representing future scenarios, estimate what will be the production of the crops. The Intergovernmental Panel on Climate Change (IPCC) made available, in its fourth report, data on the projection made for the increase in global temperature, indicating values between 1.8$3.6^{\circ} \mathrm{C}$ and an increase in the concentration of $\mathrm{CO}_{2}$ that can reach $700 \mathrm{ppm}$ in 2090-2099 (TRENBERTH et al., 2007). One of the variables that can be simulated in the search for good results, given the projected scenario, is that of irrigation management.

One of the systems that uses crop simulation models is the platform DSSAT-Decision Support System for Agrotechnology Transfer (JONES et al., 2003). This platform includes the CANEGRO model (SINGELS et al., 2008), containing support tools that assist in the manipulation of climate, soil, experimental conditions and genotype information of sugarcane crop. The system also allows seasonal and sequential simulations for the application of risk and impact studies associated with climate change (HOOGENBOOM et al., 2014). 
One of the main factors affecting the yield of any agricultural crop is water availability. It is no different for sugarcane, since the water deficit can compromise production considerably depending on the variety, the phenological stage in which the plant is located and the duration of the deficit period (FARIAS et al., 2008). Inman-Bamber \& Smith (2005) report that the sugarcane phase most susceptible to water stress is that of stem growth, as it causes a decrease in yield by reducing sucrose accumulation and phytomass production (ROBERTSON et al., 1999; SILVA \& COSTA, 2004). Thus, irrigation appears as an alternative to maintain adequate soil water conditions throughout the crop cycle.

In a study conducted by Silva et al. (2014) on the yield potential of different cultivars of sugarcane irrigated fully by drip during two cycles, the authors reported yield above the minimum required for area renewal (six cuts or up to $65 \mathrm{Mg} \mathrm{ha}^{-1}$ ). This makes it possible to increase the longevity of sugarcane, depending on the increase in production provided by irrigation. Oliveira et al. (2011) conducted a study in two environments with different water regimes and observed that there was a significant difference in crop yield, with average gains of $116 \mathrm{Mg} \mathrm{ha}^{-1}$. The authors observed that this difference can be explained by the fact that, when irrigation depths are lower than the available water storage capacity in the soil, production gains are limited. Significant increases in yield are achieved when irrigation is performed to ensure water availability throughout the growth period. This stimulates the production of cytokinin, phytomonium responsible for the vegetative growth of the plant area part (TAKEI et al., 2002). The combination of right water availability and cytokinin allows greater absorption of nutrients by the root system of the plant and, consequently, the increase in tillering and stem elongation (INMAN-BAMBER \& SMITH, 2005; SINGH et al., 2007).

Another important factor to be considered in plant production is the concentration of $\mathrm{CO}_{2}$. Knowing the prospects made for the future climate, it is extremely important to understand the effect of increasing the concentration of this gas on agricultural production. From the point of view of plant physiology, an increase in $\mathrm{CO}_{2}$ concentration would lead, first, to the partial closure of the stomata, which would reduce the stomatal conductance (VOLPE et al., 2011; MADEGOWDA MADHU \& JERRY L. HATFIELD, 2014) and respiration (KUMAR et al., 2019). Consequently, the effects of water stress would be relatively minor. Studies indicate that the increase in $\mathrm{CO}_{2}$ concentration in a controlled environment generates increases in the photosynthetic rate of sugarcane, water use efficiency, biomass production and yield (VU \& ALLEN Jr., 2009). However, 
Stokes et al. (2016) did not observe an increase in biomass production of the crop. The authors explain that the observed increase in sugarcane yield may have been influenced by the absence of water deficiency in the soil. In addition, different responses may occur due to plant age and variety used (SAGE, 2002).

Therefore, it is understood that future climatic effects on sugarcane production may vary for each region, suggesting studies with a regional focus. Thus, this study aims to evaluate the technical and economic feasibility of the implementation of an irrigation system in the sugarcane crop in the county of Ribeirão Preto, State of São Paulo, Brazil, under current and future climatic conditions.

\section{MATERIAL AND METHODS}

The simulations in this study was made using the climatic conditions of the county of Ribeirão Preto, state of São Paulo, Brazil, with headquarters located at latitude of $21^{\circ} 10^{\prime} 38^{\prime \prime}$ S, longitude $47^{\circ} 48^{\prime} 37^{\prime \prime} \mathrm{O}$ and altitude of $531 \mathrm{~m}$. The climate is characterized as semi-humid tropical, with rainy season in summer and drier season in winter (type Aw in Köppen-Geiger climatic classification). The average temperatures are higher than $18^{\circ} \mathrm{C}$ in all months of the year, with an annual average of $21.9^{\circ} \mathrm{C}$, and the rainfall index is around of $1500 \mathrm{~mm} /$ year, concentrated between October and April, with January being the month of greatest precipitation $(274 \mathrm{~mm})$. The original vegetation of the county predominates the Atlantic Forest.

\section{Model setup and data collect}

This study was conducted with the understanding of the DSSAT/CANEGRO model, using the climatic database of the Region of Ribeirão Preto (SP) (current climate) and modeling two possible futures scenarios for sugarcane crop, aiming to compare yield in rainfed and irrigated systems, as well as to estimate the feasibility of irrigation by the central pivot method in the current and future scenario. Figure 1 shows the pattern of climate variation in Ribeirão Preto (SP). 


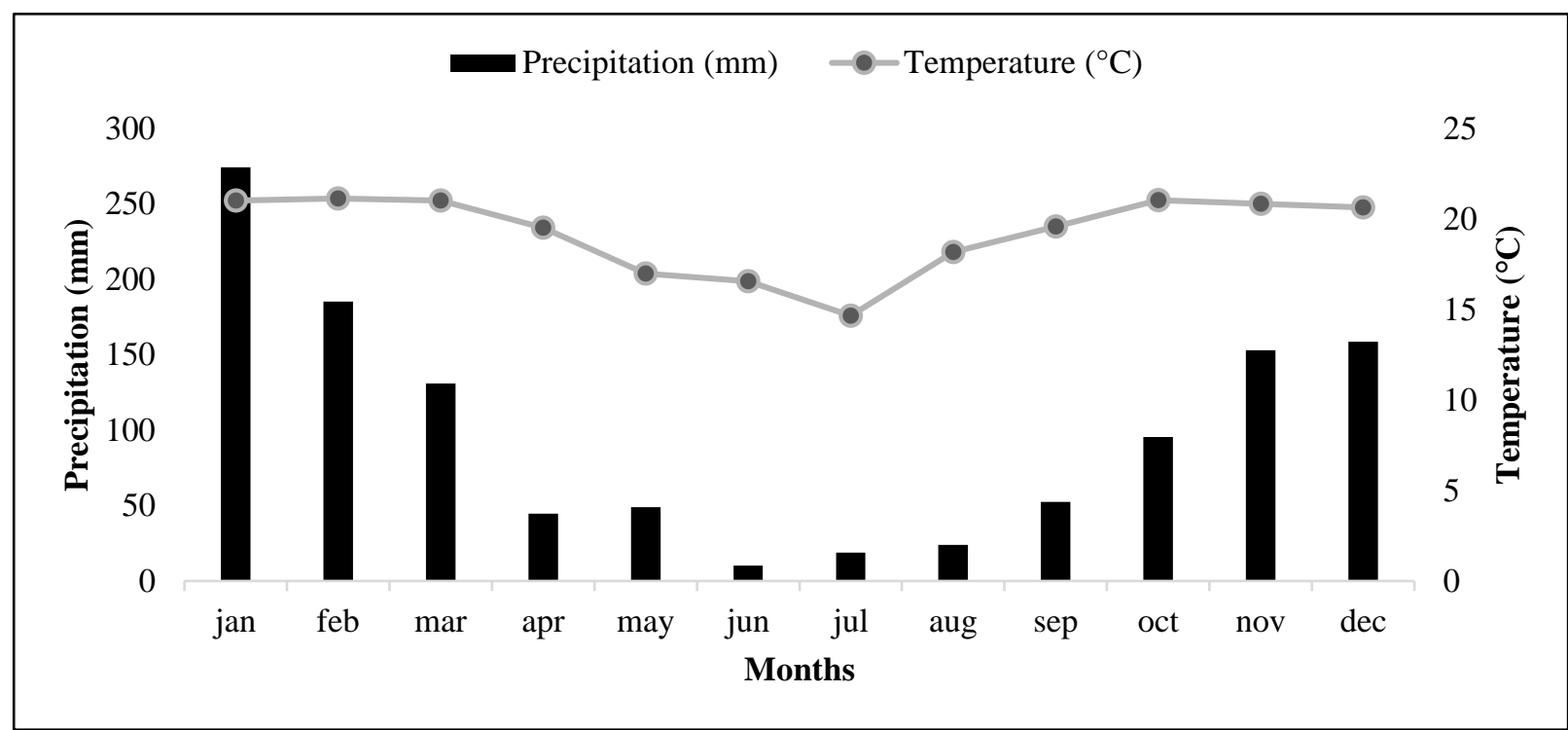

Figure 1. Monthly averages of temperature $\left({ }^{\circ} \mathrm{C}\right)$ and precipitation $(\mathrm{mm})$ for the period between 2001 and 2009 for Ribeirão Preto, São Paulo State, Brazil.

\section{Soil characterization}

Was searched Embrapa's soil profile database (EMBRAPA SOLOS, 2020) to represent the predominant soil in the simulation model, collecting soil profile data with the same classification as the studied region. Thus, the type of soil chosen for the simulations was the Red Nitosol, which has high iron content (above 15\%), has cerosity, dark red coloration, is eutrophic and has high Cation Exchange Capacity (CTC). The soil physical-water data are defined by the DSSAT itself according to the registration in the software database. As for management, it has a frequent risk of erosion due to the bumpy relief in which it is located (SOUZA; LOBATO, 2013). It is a clay soil, with a structure that favors water retention, and maintains good drainage (IAC, 2020). Such characteristics mentioned are extremely important when it comes to water availability for plant production.

\section{Planting conditions and cultivar}

The cultivar of sugarcane used was RB-867515 using the calibration provided by Marin et al (2015). The simulations were made presenting three planting dates [May 15, August (Aug) 15 and November (Nov) 15] using the period from 2001 to 2009 as a historical series for the calculations in the future scenarios. The crop cycle was 12 months, with the harvest always one 
day before planting. It was assumed that all nutritional needs of the crop were hit, so that the only variables were water availability and climate change (temperature and $\mathrm{CO}_{2}$ concentration) all over the time. The plant population considered was 15 plants. $\mathrm{m}^{-2}$ with spacing between lines of $150 \mathrm{~cm}$ and planting depth of $15 \mathrm{~cm}$.

\section{Future simulations and projections}

Combinations were made regarding the studied site, soil, cultivation system (rainfed and irrigated), planting date and current and future scenarios (Table 1).

Table 1. Schematization of the data to be simulated. Ribeirão Preto, São Paulo State, Brazil.

\begin{tabular}{cccccccc}
\hline Treatment & Local & Soil & Condition & $\begin{array}{c}\text { Planting } \\
\text { Dates }\end{array}$ & Scenario & $\begin{array}{c}\text { [CO2] } \\
\text { (ppm) }\end{array}$ & $\begin{array}{c}\text { Historical } \\
\text { Series }\end{array}$ \\
\hline \multirow{2}{*}{1} & Ribeirao & Red & \multirow{2}{*}{ Rainfed } & $\begin{array}{c}\text { May 15 } \\
\text { Aug 15 }\end{array}$ & $\begin{array}{c}\text { Current } \\
\text { Future (B1) }\end{array}$ & $\begin{array}{c}415 \\
528\end{array}$ & $2001-2009$ \\
& Preto & Nitosol & & Nov 15 & Future (B2) & 528 & \\
\hline \multirow{2}{*}{2} & & & & May 15 & Current & 415 & \\
& Ribeirao & Red & \multirow{2}{*}{ Irrigated } & Aug 15 & Future (B1) & 528 & $2001-2009$ \\
& Preto & Nitosol & & Nov 15 & Future (B2) & 528 & \\
\hline
\end{tabular}

Subtitle: $\left[\mathrm{CO}_{2}\right]-\mathrm{CO}_{2}$ Concentration in ppm (parts per million)

The simulations with irrigation were made to add water automatically just when necessary, according to the weather in each year simulated, to supply the water demand of the crop and the deficiency of rain. The same procedure was performed for future scenarios. Two future scenarios were proposed for rainfall: an increase of $10 \%$ (B1) and a 10\% reduction (B2); one future temperature scenario: increase of $2^{\circ} \mathrm{C}$; and an increase in atmospheric $\mathrm{CO}_{2}$ concentration to 528 ppm.

\section{Simulation environment}

The yield of Fresh Stalk Yield of the stem (FSY, Mg ha ${ }^{-1}$ ), Sucrose Yield (SY, Mg ha-1) and water productivity (WP, $\mathrm{kg}$ of dry matter $\mathrm{mm}^{-1}$ ) were simulated, considering dry matter yield values (DMY, $\mathrm{Mg} \mathrm{ha}^{-1}$ ), in the regimes of rainfed (rain) and irrigated (rain and irrigation) using the 
CANEGRO model (INMAN-BAMBER,1991; SINGELS et al., 2008). This model simulates the growth dynamics, which involves the production of phytomass, and the development of sugarcane, involving the accumulation of sucrose with consequent stretching of the stems. For simulation, was used meteorological data of the region, management characteristics of the production environment, characteristics of the chosen cultivar and soil properties, such as soil content, factors that can affect photosynthesis, growth, transpiration rate and carbohydrate partition (PAGANI et al., 2017).

To quantify the production of phytomass per unit of area, or yield and sucrose production, as well as its accumulation in the stems, the DSSAT/CANEGRO model uses as a calculation basis the quantification of photosynthesis through the calculation of daily biomass increment $\left(\mathrm{PG}, \mathrm{g} \mathrm{m}^{-}\right.$ ${ }^{2} \mathrm{~d}^{-1}$ ), which, at the end of the harvest period, was named Fresh stalk yield being the sum of PG daily until harvest. The calculation is based on the efficiency of radiation use (SINGELS \& BEZUIDENHOUT, 2002) and an algorithm for computing fertilization caused by atmospheric $\mathrm{CO}_{2}$ (SINGELS et al., 2013), as follows in equation 1:

$$
P_{G}=F I * P A R * R U E * R_{P G} \quad \text { Equation } 1 .
$$

Where FI is the intercept fraction of the flux density of photosynthetically active photons (PAR, MJ m${ }^{-2}$ ) and RUE is the efficiency of radiation use $\left(\mathrm{g} \mathrm{MJ}^{-1}\right)$. The default value of $\left[\mathrm{CO}_{2}\right]=330$ ppm is used by the model for calculating $\mathrm{P}_{\mathrm{G}}$ and is then adjusted by the adjustment factor ( $\mathrm{R}_{\mathrm{PG}}$ ) that depends on $\left[\mathrm{CO}_{2}\right]$. The value of $\mathrm{R}_{\mathrm{PG}}$ is calculated by combining a set of coordinated points. Each of these points is defined in the DSSAT System species file and a corn-derived function (extracted from the source code of the 2011 version of DSSAT v 4.5).

Water productivity is simulated from a derivation of the method proposed by Martiné et al. (2003), with adjustments included based on the experiments by Nassif et al. (2013). The equations below are used to calculate the rate of variation of the water mass in the stem each day, taking into an account dry matter and accumulated sucrose mass.

$$
\begin{aligned}
& d S T K W \text { ater }=(3,607 * d W S)-(3,078 * d W S u c) \quad \forall S W F P>0,6 \quad \text { Equação } 2 . \\
& d S T K W a t e r=(\text { STKURed } * W S) \quad \forall S W F P \leq 0,6 \quad \text { Equação } 3 .
\end{aligned}
$$


In which dSTKWater is the daily increment rate of water per mass of stem, dWS is the daily increment rate of structural dry matter of the stem; dWSuc is the daily increment rate of sucrose mass in the stem; STKURed is a factor in reducing the rate of water in the stem in conditions of severe drought and that varies as a function of stem mass and humidity, varying as shown in Figure 2.

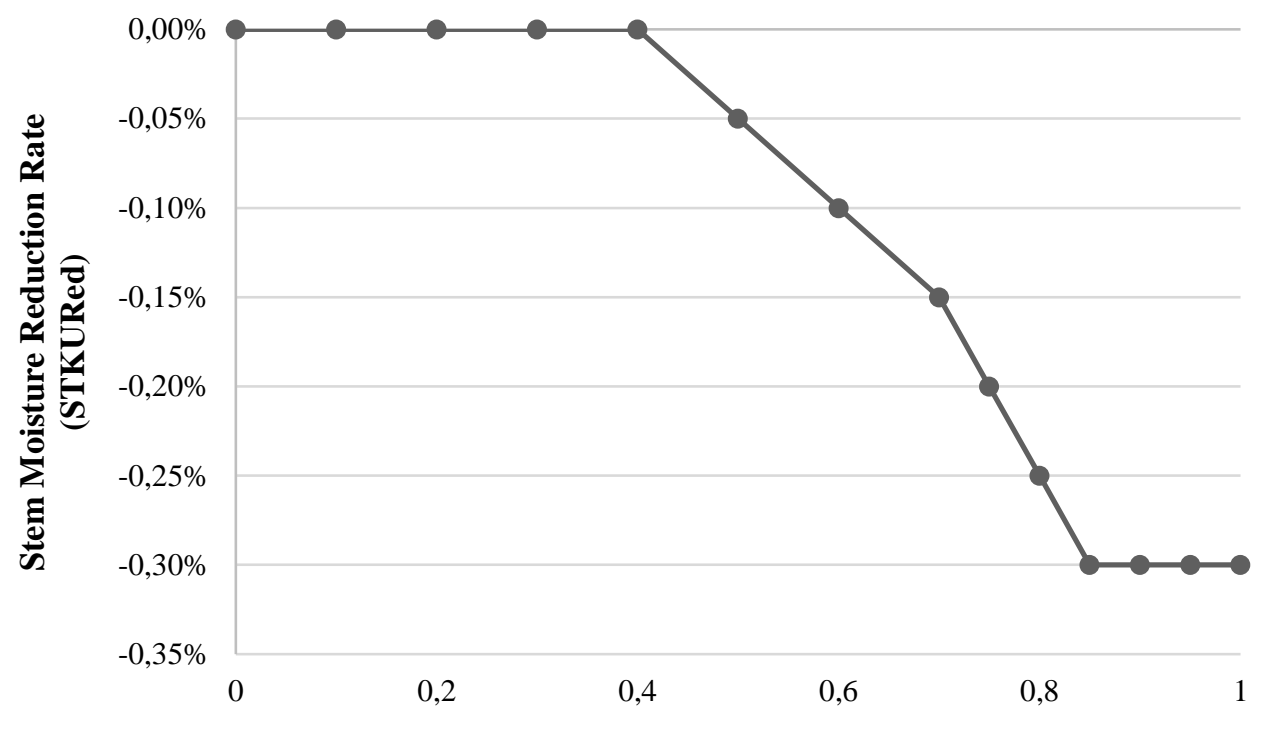

Stalk Moisture

Figure 2. Variation of the rate of reduction of relative stem moisture as a function of stalk moisture and total stem mass, under severe water stress conditions. Source: MARIN (2014).

\section{Economic feasibility analysis}

For economic feasibility analysis for investments in the agro-industrial chain of sugarcane, it is necessary to understand how the sugarcane payment system called "Sucrose Sugarcane Payment" (PCTS from the Portuguese acronymous) works, which follows the standards of the CONSECANA for the calculation of the industrials technological parameters of sugarcane. Some variables are obtained specifically with the aid of equipment that gives the value directly, which can be changed throughout the harvest period. Table 2 shows an example of these parameters. The rest are obtained through formulas to get in the final and most important equation as shown in Equation 4. It was provided by the CONSECANA, with the purpose of calculating the value of Total Sugar Recovered (ATR in $\mathrm{kg} \mathrm{ha}^{-1}$ ), a parameter priced in the market. Payment is made from the result of ATR (CONSECANA, 2006). 
Table 2. Industrial Qualitative Parameters analyzed with measurements equipment. Ribeirão Preto, São Paulo State, Brazil.

\section{Sugarcane Industrial Parameters}

Analisy Period

${ }^{\circ}$ Brix

Weight of humid mass $(\mathrm{g})$

LAI

$\mathrm{S}$

Legend: Brix - Soluble solids; LAI - Saccharimeter reading obtained with aluminum-based clarifying mixture; $\mathrm{S}$ - Pol of extracted broth.

$\operatorname{ATR}\left(\mathrm{kg} \mathrm{ton}^{-1}\right)=(9,6316 *$ POL CANE $(\%)+9,15 * \operatorname{ARC}(\%)) * 10$
August

20

130

70

11

Thus, for this work, estimates were made for the three cut-off dates, both for the current scenario and for the future, calculating the arithmetic mean of FSY and SY parameters and using the 9 years of simulation. Next, the arithmetic mean was calculated again for both variables analyzed, using the three planting dates. With this it was possible to calculate the amount of ATR, in $\mathrm{kg} \mathrm{Mg}^{-1}$ of sugarcane, for all scenarios considered, from the sucrose contents found.

In addition, a hypothetical area of 5,000 ha was considered, and it is worth mentioning that, in smaller and/or larger areas, the result will be the same in relation to the interpretation of the data acquired through the economic feasibility study of the proposed system, both for the current scenario and for the future. In addition, the cost of sugarcane implantation used was $\mathrm{R} \$ 6,258.41$ $\mathrm{ha}^{-1}$ (Table 3), the sugarcane maintenance cost was $\mathrm{R} \$ 1,193.58 \mathrm{ha}^{-1}$ (Table 4) and the implantation pivot (CAPEX) was $\mathrm{R} \$ 7,738.79 \mathrm{ha}^{-1}$ (Table 5) with the annual maintenance cost (OPEX) of the equipment of $\mathrm{R} \$ 1,335.25 \mathrm{ha}^{-1}$ (Table 5). It is worth mentioning that the cost calculation of operations as well as equipment were made considering the cost table for 2014 updated for the year 2018 using the value of General Price Index in di mode (IGP-DI) of 1.23. 
Table 3. Table of costs for the implantation of the sugarcane field. Ribeirão Preto, São Paulo State, Brazil. 2018.

\begin{tabular}{|c|c|}
\hline OPERATION & $\operatorname{COST}\left(\mathbf{R} \$ h^{-1}\right)$ \\
\hline I. PREPARING THE SOIL & - \\
\hline 1. GRADATION (HEAVY) & $\mathrm{R} \$ 120.07$ \\
\hline 2. PALLIATION & $\mathrm{R} \$ 173.41$ \\
\hline 3. GRADATION (HEAVY) & $\mathrm{R} \$ 120.07$ \\
\hline 4. GRADATION (LIGHT) & $\mathrm{R} \$ 75.69$ \\
\hline 5. CARCARRIER MARKING & $\mathrm{R} \$ 20.51$ \\
\hline 6. TERRACE & $\mathrm{R} \$ 42.00$ \\
\hline 7. APPLICATION OF LIMESTONE & $\mathrm{R} \$ 43.39$ \\
\hline 8. CALCARIUM & $\mathrm{R} \$ 219.88$ \\
\hline 9. ADMINISTRATOR (10\%) & $\mathrm{R} \$ 81.50$ \\
\hline SUBTOTAL & R\$ 896.53 \\
\hline II- PLANTING & - \\
\hline 1. SULCATION & $\mathrm{R} \$ 182.09$ \\
\hline 2. FERTILIZER & $\mathrm{R} \$ 641.21$ \\
\hline 3. MUTE CUT (CLEAN) & $\mathrm{R} \$ 303.46$ \\
\hline 4. SEEDLING & $\mathrm{R} \$ 2,358.49$ \\
\hline 5. LOADING CHANGES & $\mathrm{R} \$ 51.59$ \\
\hline 6. SHIPPING CHANGES & $\mathrm{R} \$ 107.90$ \\
\hline 7. STEMS CUTTING & $\mathrm{R} \$ 366.74$ \\
\hline 8. FINISHING AND RECOVERY & $\mathrm{R} \$ 177.83$ \\
\hline 9. RECOVERY & $\mathrm{R} \$ 46.92$ \\
\hline 9.1. INSETICIDE & $\mathrm{R} \$ 214.97$ \\
\hline 10. HERBICIDE APPLICATION & $\mathrm{R} \$ 35.24$ \\
\hline 11. HERBICIDE & $\mathrm{R} \$ 131.93$ \\
\hline 12. ANT CONTROL & $\mathrm{R} \$ 1.41$ \\
\hline 12.1. DRILL CONTROL & $\mathrm{R} \$ 19.65$ \\
\hline 13. CARPA CONTROL & $\mathrm{R} \$ 158.87$ \\
\hline 14. LOMBO BREAK & $\mathrm{R} \$ 76.15$ \\
\hline 15. ADMINISTRATOR (10\%) & $\mathrm{R} \$ 487.45$ \\
\hline SUBTOTAL & $\mathbf{R} \$ 5,361.87$ \\
\hline TOTAL & $\mathrm{R} \$ \mathbf{6 , 2 5 8 . 4 1}$ \\
\hline
\end{tabular}

Source: GALINDO \& CARVALHO, 2016. 
Table 4. Table of costs for maintaining the cane field. Ribeirão Preto, São Paulo State, Brazil. 2018.

\begin{tabular}{lc}
\hline OPERATION & COST $\left(\mathbf{R} \mathbf{\text { ha }} \mathbf{- 1}^{\mathbf{1}}\right)$ \\
\hline I. MANAGEMENT OF 2nd HARVEST AND BEYOND & - \\
1. UNRAKE & $\mathrm{R} \$ 29.60$ \\
2. CULTIVATION & $\mathrm{R} \$ 153.12$ \\
3. FERTILIZER & $\mathrm{R} \$ 436.69$ \\
4. HERBICIDE APPLICATION & $\mathrm{R} \$ 35.24$ \\
5. HERBICIDE & $\mathrm{R} \$ 74.93$ \\
6. ANT CONTROL & $\mathrm{R} \$ 1.41$ \\
6.1. DRILL CONTROL & $\mathrm{R} \$ 19.65$ \\
6.2. CIGARRINHA'S CONTROL & $\mathrm{R} \$ 108.10$ \\
7. CARPA CONTROL & $\mathrm{R} \$ 226.33$ \\
9. ADMINISTRATOR (10\%) & $\mathrm{R} \$ 108.50$ \\
\hline SUBTOTAL & $\mathbf{R} \mathbf{1 , \mathbf { 1 9 3 . 5 8 }}$ \\
\hline
\end{tabular}

Source: GALINDO \& CARVALHO, 2016.

Table 5. Table of investment costs for the used central pivot irrigation system (CAPEX) and equipment maintenance costs over a 15 year useful life (OPEX). Ribeirão Preto, São Paulo State, Brazil. 2018.

\begin{tabular}{|c|c|}
\hline DESCRIPTION & PIVOT \\
\hline APPLICATION EFFICIENCY RATE & $85 \%$ \\
\hline APPLIED DEPTH (mm) & 500 \\
\hline INFRASTRUCTURE INVESTMENT & $\mathrm{R} \$ 1,228.38$ \\
\hline \multicolumn{2}{|c|}{ EQUIPMENT (IRRIGATION SYSTEM/SET MOTOR } \\
\hline PUMP/TUBES/TRACTOR) & $\mathrm{R} \$ 6,141.90$ \\
\hline INSTALLATION & $\mathrm{R} \$ 368.51$ \\
\hline CAPEX/HA & $\mathbf{R} \$ \mathbf{7 , 7 3 8 . 7 9}$ \\
\hline ENERGY (R\$HA) & $\mathrm{R} \$ 541.72$ \\
\hline DIESEL OIL / TRACTOR (R $\$ / \mathrm{HA})$ & $\mathrm{R} \$ 8.60$ \\
\hline MAINTENANCE (R \$/HA) & $\mathrm{R} \$ 232.16$ \\
\hline ADMINISTRATIVE EXPENSES & $\mathrm{R} \$ 85.99$ \\
\hline EMPLOYEE (R\$/HA) & $\mathrm{R} \$ 466.78$ \\
\hline OPEX/HA & $\mathrm{R} \$ \mathbf{1 , 3 3 5 . 2 5}$ \\
\hline $\mathrm{R} \$ / \mathrm{MM}$ APPLIED & $\mathrm{R} \$ 3.44$ \\
\hline R \$/ MM EFFECTIVE* & $\mathrm{R} \$ 4.05$ \\
\hline
\end{tabular}

*Applied blade (mm) multiplied by the application efficiency rate.

The variables used to assess the economic viability of irrigation were: (i) Net Present Value (NPV), an important tool to determine the present value of future payments discounted at an appropriate interest rate, minus the cost of the initial investment, according to equation 5 
(MACEDO, 2007). It is from the NPV that the options will be analyzed and that will assist in the decision-making as to the realization of the investment or not, as shown in table 6; (ii) Internal Rate of Return (IRR), considered to calculate the discount rate that must have a cash flux so that your NPV equals zero (CRUZ, 2011). It is observed that when an investment is proposed the IRR must be greater than zero and the NPV, positive, to ensure that the investment will bring profit. To complement the analysis, the return period of the investment in question ("payback period" or ROI (Return on Investment)) was identified to check, at the end of the analysis, whether the investment is economically viable, and the time required for the return on capital invested to an investor, in the form of net profit (2011).

$$
N P V=\sum_{j=1}^{n} \frac{F C_{j}}{(1+i)^{j}}-F C_{0} \quad \text { Equation } 5 .
$$

where NPV is the net present value $(\mathrm{R} \$)$;

$\mathrm{FC}_{0}$ is the initial investment cost $(\mathrm{R} \$)$;

$\mathrm{FC}_{\mathrm{j}}$ is the inputs (revenues) and outflows (costs) expected for each future period ( $\mathrm{R} \$$ );

$\mathrm{i}$ is the interest rate or discount rate $(\%)$;

$\mathrm{j}$ is the period;

$\mathrm{n}$ is the project life (years).

Table 6. Decision making considering the value of the NPV.

\begin{tabular}{cc}
\hline Calculated NPV condition & Likely decision-making \\
\hline $\mathrm{NPV}>0$ & Realization of the investment \\
$\mathrm{NPV}<0$ & $\begin{array}{c}\text { Non-realization of the investment } \\
\mathrm{NPV}=0\end{array}$ \\
\end{tabular}

\section{RESULTS AND DISCUSSION}

\section{Fresh stalk yield and sucrose yield}

Tables 7 and 8 show the values of Fresh Stalk Yield (FSY) and Sucrose Yield (SY) in Mg $\mathrm{ha}^{-1}$ for sugarcane under rainfed and irrigated cultivation conditions for three distinct planting dates in the current scenario. It was noted that there was higher production of fresh stalk and sucrose in 
the planting treatment in May, for both cultivation conditions. Both yields were higher in the irrigated environment compared to the rainfed condition. In several crops, irrigation is observed to supply the water demand of plants and promotes an increase in potential yield.

Figure 3 shows the variation in the amount of fresh stalk produced by sugarcane each year, together with sucrose yield. In 2004, the highest yield values were obtained for the two cultivation conditions (rainfed and irrigated). The use of irrigation resulted in an increase of $4.02 \%$ for FSY and a drop of $2 \%$ for SY. Water availability defined the establishment of the crop during the vegetative stage (RAMESH, 2000), that is, the lack of water during this initial period can reduce biomass and sucrose production. However, if the vegetative phase of the production cycle has passed, the lack of water may compromise the production of phytomass, but not the production of sucrose that can even be increased, because vegetative growth occurs in order to compete with the sucrose accumulation process (FARIAS, 2008). That is, in moments that provide vegetative growth of the plant, sucrose accumulation will be minimal. Only when the conditions begin to limit the vegetative phase that the plant begins its process of sucrose accumulation in the stem, in the socalled maturation phase (FARIAS, 2008). Thus, there was an increase in biomass yield and a slight fall in sucrose accumulation.

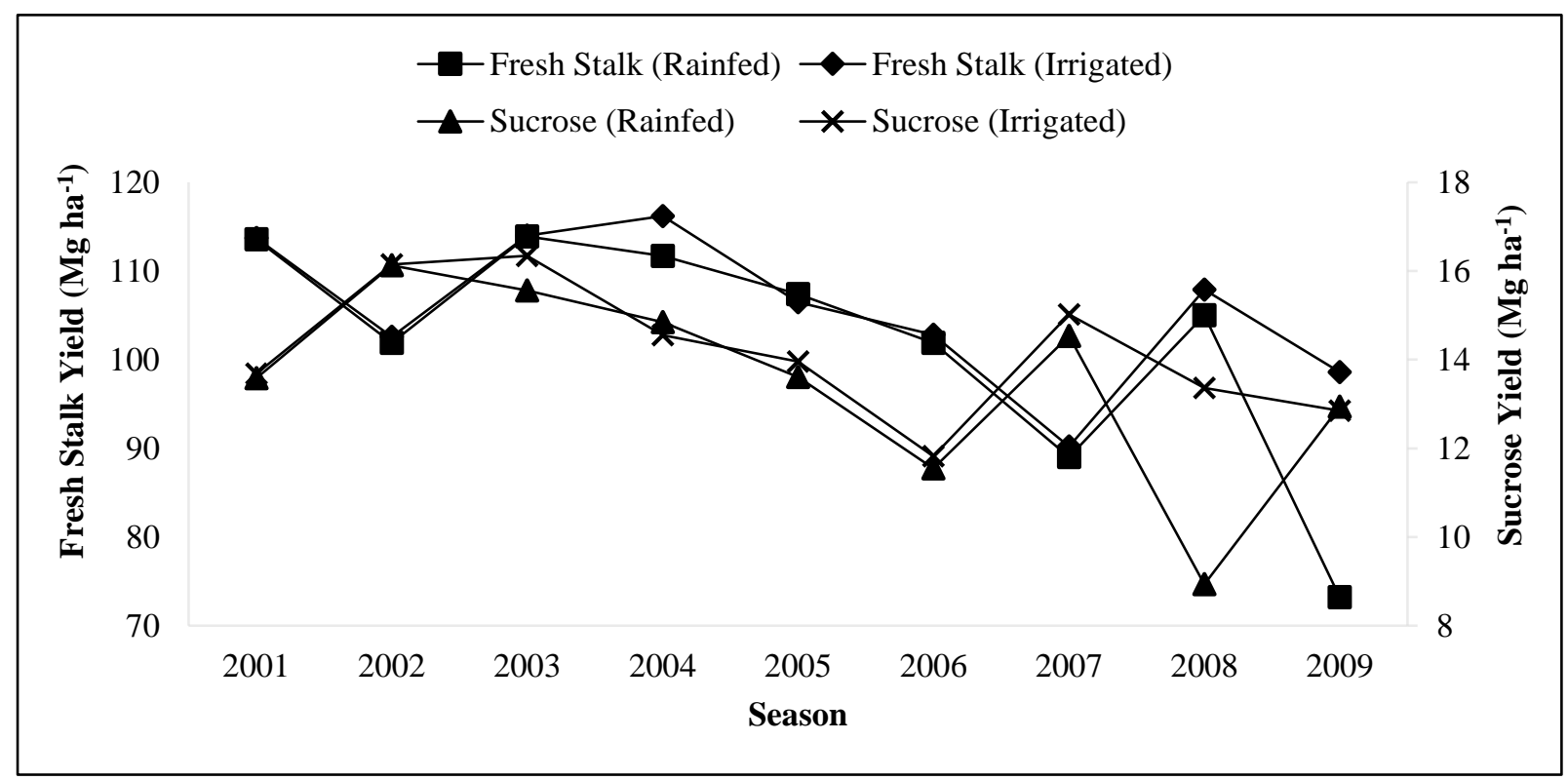

Figure 3. Fresh stalk yield (FSY) and sucrose yield (SY), under rainfed and irrigated conditions, for the best planting date (May/15), in the current scenario. Ribeirão Preto, São Paulo State, Brazil. 
Table 7. Fresh stalk yield (FSY) and sucrose yield (SY) for the condition of sugarcane cultivation in rainfed environment, for three different planting dates, in the current scenario. Ribeirão Preto, São Paulo State, Brazil.

\begin{tabular}{|c|c|c|c|c|c|c|}
\hline \multirow{2}{*}{ Scenario } & \multicolumn{6}{|c|}{ Current Scenario - Rainfed Condition } \\
\hline & \multirow{2}{*}{\multicolumn{3}{|c|}{$\begin{array}{c}\text { FSY } \\
\text { Mg ha-1 }^{-1}\end{array}$}} & \multirow{2}{*}{\multicolumn{3}{|c|}{$\begin{array}{c}\text { SY } \\
\text { Mg ha'-1 }^{-1}\end{array}$}} \\
\hline \multirow{2}{*}{ Year } & & & & & & \\
\hline & May 15 & Aug 15 & Nov 15 & May 15 & Aug 15 & Nov 15 \\
\hline 2001 & 120.8 & 113.6 & 71.0 & 16.1 & 13.6 & 5.2 \\
\hline 2002 & 115.0 & 101.9 & 56.7 & 15.6 & 16.1 & 6.8 \\
\hline 2003 & 116.4 & 113.9 & 65.9 & 15.2 & 15.6 & 7.7 \\
\hline 2004 & 109.9 & 111.7 & 71.5 & 14.1 & 14.9 & 6.3 \\
\hline 2005 & 108.1 & 107.4 & 68.4 & 14.2 & 13.6 & 7.2 \\
\hline 2006 & 103.6 & 101.9 & 69.3 & 13.5 & 11.5 & 4.7 \\
\hline 2007 & 92.9 & 89.0 & 47.8 & 11.2 & 14.5 & 7.9 \\
\hline 2008 & 94.7 & 105.0 & 70.9 & 12.0 & 8.9 & 7.7 \\
\hline 2009 & 115.6 & 73.2 & 75.8 & 16.0 & 12.9 & 4.6 \\
\hline Mean & 108.6 & 102.0 & 66.4 & 14.2 & 13.5 & 6.4 \\
\hline
\end{tabular}

Table 8. Fresh stalk yield (FSY) and sucrose yield (SY) for the condition of sugarcane cultivation in an irrigated environment, for three different planting dates, in the current scenario. Ribeirão Preto, São Paulo State, Brazil.

\begin{tabular}{|c|c|c|c|c|c|c|}
\hline \multirow{2}{*}{ Scenario } & \multicolumn{6}{|c|}{ Current Scenario - Irrigated Condition } \\
\hline & \multirow{2}{*}{\multicolumn{3}{|c|}{$\begin{array}{c}\text { FSY } \\
\text { Mg ha }^{-1}\end{array}$}} & \multirow{2}{*}{\multicolumn{3}{|c|}{$\begin{array}{c}\text { SY } \\
\text { Mg ha' }^{-1}\end{array}$}} \\
\hline \multirow{2}{*}{ Year } & & & & & & \\
\hline & May 15 & Aug 15 & Nov 15 & May 15 & Aug 15 & Nov 15 \\
\hline 2001 & 120.6 & 113.7 & 72.8 & 16.7 & 13.7 & 5.5 \\
\hline 2002 & 123.1 & 102.6 & 58.7 & 16.5 & 16.1 & 6.8 \\
\hline 2003 & 117.8 & 114.0 & 65.9 & 16.1 & 16.3 & 7.9 \\
\hline 2004 & 120.6 & 116.2 & 72.7 & 16.1 & 14.6 & 6.3 \\
\hline 2005 & 114.3 & 106.5 & 68.4 & 14.8 & 14.0 & 7.7 \\
\hline 2006 & 114.0 & 102.8 & 72.5 & 15.3 & 11.8 & 4.9 \\
\hline 2007 & 109.5 & 90.2 & 52.5 & 14.6 & 15.0 & 7.8 \\
\hline 2008 & 103.4 & 107.9 & 70.7 & 13.1 & 13.4 & 7.7 \\
\hline 2009 & 97.9 & 98.6 & 75.8 & 12.6 & 12.8 & 4.9 \\
\hline Mean & 113.5 & 105.8 & 67.8 & 15.1 & 14.2 & 6.6 \\
\hline
\end{tabular}

Using the average annual yield values obtained on the three planting dates, it is possible to observe that, comparing the current scenario and the future scenario B1, there is an increase in yield of $22 \%$ for the rainfed and $33 \%$ for irrigated. The increase in yield should not be analyzed as a single variable, due to the interactions between environmental factors and plant genotype. 
Together, such interactions in the climatic scenarios simulated in this experiment resulted in an increase in the yields (FSY and SY) of the sugarcane variety studied.

It was also observed that the mean of FSY in the rainfed cultivation condition with planting in August was 119.4 $\mathrm{Mg} \mathrm{ha}^{-1}$ (Table 9), and an irrigated cultivation was $137.3 \mathrm{Mg} \mathrm{ha}^{-1}$ (Table 10). These values were higher than those of the current scenario with planting in the same month (means of FSY of 102 and $105.8 \mathrm{Mg} \mathrm{ha}^{-1}$, (Tables 7 and 8). In addition, in the rainfed cultivation, the highest FSY was obtained with planting in August (119.4 $\left.\mathrm{Mg} \mathrm{ha}^{-1}\right)$ and in irrigated cultivation, with planting in May (141.6 $\left.\mathrm{Mg} \mathrm{ha}^{-1}\right)$. It is noteworthy that the gains in terms of agricultural yield with the use of irrigation in management range from 1.2 to $32.8 \mathrm{Mg} \mathrm{ha}^{-1}$. For sucrose yield, the average annual values were 14 and $15.9 \mathrm{Mg} \mathrm{ha}^{-1}$ under the conditions of sucrose and irrigated, respectively, which were above the current average of 11.4 and $11.9 \mathrm{Mg} \mathrm{ha}^{-1}$.

Table 9. Fresh stalk yield (FSY) and sucrose yield (SY) for the condition of sugarcane cultivation in rainfed environment, for three different planting dates, in the future scenario B1. Ribeirão Preto, São Paulo State, Brazil.

\begin{tabular}{|c|c|c|c|c|c|c|}
\hline \multirow{4}{*}{$\begin{array}{c}\text { Scenario } \\
\text { Year }\end{array}$} & \multicolumn{6}{|c|}{ Future Scenario B1 - Rainfed Condition } \\
\hline & \multirow{2}{*}{\multicolumn{3}{|c|}{$\begin{array}{l}\text { FSY } \\
\text { t/ha }\end{array}$}} & \multirow{2}{*}{\multicolumn{3}{|c|}{$\begin{array}{c}\text { SY } \\
\text { t/ha }\end{array}$}} \\
\hline & & & & & & \\
\hline & May 15 & Aug 15 & Nov 15 & May 15 & Aug 15 & Nov 15 \\
\hline 2050 & 130.1 & 127.3 & 106.4 & 16.4 & 16.8 & 10.1 \\
\hline 2051 & 132.1 & 120.8 & 87.2 & 15.7 & 13.5 & 12.2 \\
\hline 2052 & 126.2 & 111.2 & 99.1 & 16.2 & 16.8 & 14.3 \\
\hline 2053 & 125.3 & 124.4 & 109.5 & 14.3 & 17.7 & 11.3 \\
\hline 2054 & 115.8 & 126.0 & 99.4 & 15.0 & 16.0 & 10.4 \\
\hline 2055 & 118.7 & 119.4 & 93.0 & 14.0 & 13.9 & 9.4 \\
\hline 2056 & 114.5 & 113.8 & 74.3 & 12.6 & 12.9 & 12.9 \\
\hline 2057 & 105.2 & 100.7 & 101.3 & 13.0 & 15.7 & 13.0 \\
\hline 2058 & 108.5 & 113.7 & 108.7 & 17.7 & 9.4 & 10.3 \\
\hline Mean & 118.7 & 119.4 & $\begin{array}{l}99.4 \\
\end{array}$ & 15.0 & 15.7 & 11.3 \\
\hline
\end{tabular}


Table 10. Fresh stalk yield (FSY) and sucrose yield (SY) for the condition of sugarcane cultivation in an irrigated environment, for three different planting dates, in the future scenario B1. Ribeirão Preto, São Paulo State, Brazil.

\begin{tabular}{|c|c|c|c|c|c|c|}
\hline \multirow{2}{*}{ Scenario } & \multicolumn{6}{|c|}{ Future Scenario B1 - Irrigated Condition } \\
\hline & \multirow{2}{*}{\multicolumn{3}{|c|}{$\begin{array}{l}\text { FSY } \\
\text { t/ha }\end{array}$}} & \multirow{2}{*}{\multicolumn{3}{|c|}{$\begin{array}{c}\text { SY } \\
\text { t/ha }\end{array}$}} \\
\hline \multirow{2}{*}{ Year } & & & & & & \\
\hline & May 15 & Aug 15 & Nov 15 & May 15 & Aug 15 & Nov 15 \\
\hline 2001 & 149.2 & 140.3 & 109.2 & 19.7 & 18.1 & 10.9 \\
\hline 2002 & 150.1 & 137.3 & 90.7 & 19.5 & 20.4 & 12.7 \\
\hline 2003 & 146.2 & 143.0 & 102.4 & 19.5 & 21.3 & 14.4 \\
\hline 2004 & 148.2 & 149.1 & 111.8 & 17.7 & 18.3 & 11.6 \\
\hline 2005 & 140.4 & 138.7 & 101.7 & 18.1 & 17.4 & 11.2 \\
\hline 2006 & 141.6 & 133.5 & 97.6 & 17.6 & 16.3 & 9.7 \\
\hline 2007 & 134.2 & 121.7 & 77.9 & 16.3 & 18.0 & 13.3 \\
\hline 2008 & 127.7 & 133.5 & 103.6 & 16.0 & 17.0 & 13.3 \\
\hline 2009 & 127.6 & 124.9 & 109.9 & 20.1 & 18.2 & 10.7 \\
\hline Mean & 141.6 & 137.3 & 102.4 & 18.1 & 18.1 & 11.6 \\
\hline
\end{tabular}

In Figure 4, the variation in the yield of fresh stalk and sucrose over the years can be seen, for the best planting date (August). It is noted that in some years the use of irrigation has not resulted in significant gains in agricultural income. That is, even with the use of irrigation, environmental variations are a factor that interferes in sugarcane yield, and it is necessary to intervene in the genetic order, at times.

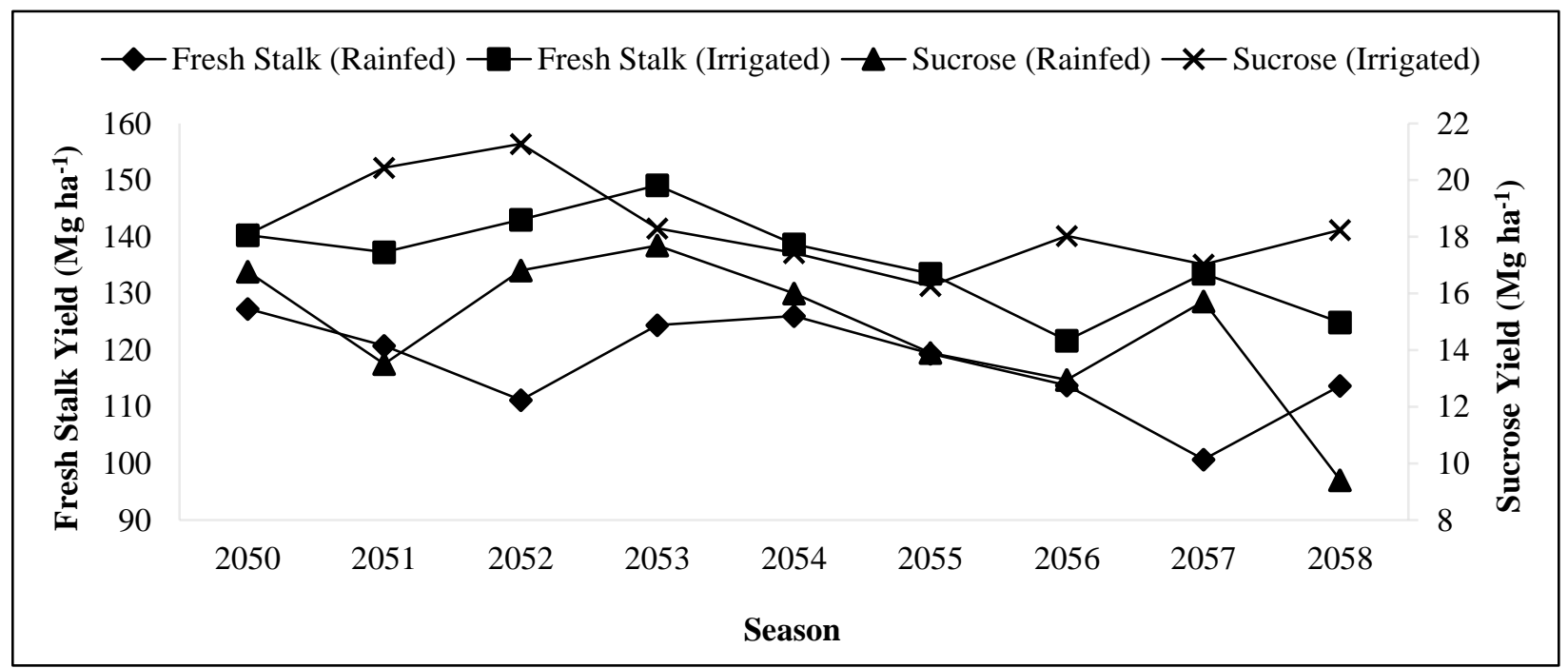

Figure 4. Stem Fresh stalk yield and sucrose yield, under rainfed and irrigated conditions, for the best planting date (Aug. 15), in future scenario B1. Ribeirão Preto, São Paulo State, Brazil. 
The values of FSY and SY in scenario B2 can be seen in Tables 11 and 12. In the same way as occurred in scenario B1, there was an increase in the average annual FSY, compared to the current scenario, $20 \%$ in rainfed cultivation $\left(111.1 \mathrm{Mg} \mathrm{ha}^{-1}\right)$ and $32 \%$ in irrigated cultivation (126.5 $\mathrm{Mg} \mathrm{ha}^{-1}$ ). Therefore, it is understood that there will be no drop in agricultural yield of the variety studied in a future scenario whose water regime will suffer a $10 \%$ reduction, even in rainfed conditions. Sucrose yield may increase from 11.4 to $13.9 \mathrm{Mg} \mathrm{ha}^{-1}(+21.9 \%)$ in rainfed cultivation and from 12.0 to $16.5 \mathrm{Mg} \mathrm{ha}^{-1}(+37.5 \%)$ in irrigated cultivation. In addition, yield gains may vary from 3.5 to $39.5 \mathrm{Mg} \mathrm{ha}^{-1}$, depending on the planting date and the year analyzed.

Table 11. Fresh stalk yield (FSY) and sucrose yield (SY) for sugarcane in rainfed cultivation, for three distinct planting dates, in future scenario B2. Ribeirão Preto, São Paulo State, Brazil.

\begin{tabular}{|c|c|c|c|c|c|c|}
\hline \multirow{4}{*}{$\begin{array}{c}\text { Scenario } \\
\text { Year }\end{array}$} & \multicolumn{6}{|c|}{ Future Condition B2 Rainfed } \\
\hline & \multirow{2}{*}{\multicolumn{3}{|c|}{$\begin{array}{l}\text { FSY } \\
\text { t/ha }\end{array}$}} & \multirow{2}{*}{\multicolumn{3}{|c|}{$\begin{array}{l}\text { SY } \\
\text { t/ha }\end{array}$}} \\
\hline & & & & & & \\
\hline & May 15 & Aug 15 & Nov 15 & May 15 & Aug 15 & Nov 15 \\
\hline 2050 & 130.8 & 123.7 & 97.1 & 17.8 & 16.4 & 8.8 \\
\hline 2051 & 138.4 & 129.5 & 78.3 & 17.5 & 19.0 & 11.3 \\
\hline 2052 & 134.6 & 133.3 & 92.2 & 17.1 & 19.9 & 13.3 \\
\hline 2053 & 134.5 & 138.8 & 103.2 & 14.7 & 16.9 & 9.6 \\
\hline 2054 & 115.8 & 124.3 & 86.9 & 15.8 & 15.7 & 9.0 \\
\hline 2055 & 117.3 & 122.4 & 81.5 & 13.9 & 14.2 & 8.4 \\
\hline 2056 & 113.1 & 107.8 & 68.7 & 14.7 & 16.2 & 12.4 \\
\hline 2057 & 117.4 & 117.2 & 96.2 & 13.0 & 14.1 & 11.7 \\
\hline 2058 & 106.1 & 104.0 & 100.0 & 18.0 & 17.0 & 8.6 \\
\hline Mean & 117.4 & 123.7 & 92.2 & 15.8 & 16.4 & 9.6 \\
\hline
\end{tabular}


Table 12. Fresh stalk yield (FSY) and sucrose yield (SY) for sugarcane in irrigated cultivation, for three distinct planting dates, in future scenario B2. Ribeirão Preto, São Paulo State, Brazil.

\begin{tabular}{|c|c|c|c|c|c|c|}
\hline \multirow{4}{*}{$\begin{array}{c}\text { Scenario } \\
\text { Year }\end{array}$} & \multicolumn{6}{|c|}{ Future Condition B2 Irrigated } \\
\hline & \multirow{2}{*}{\multicolumn{3}{|c|}{$\begin{array}{l}\text { FSY } \\
\text { t/ha }\end{array}$}} & \multirow{2}{*}{\multicolumn{3}{|c|}{$\begin{array}{l}\text { SY } \\
\text { t/ha }\end{array}$}} \\
\hline & & & & & & \\
\hline & May 15 & Aug 15 & Nov 15 & May 15 & Aug 15 & Nov 15 \\
\hline 2001 & 137.7 & 127.9 & 126.4 & 19.1 & 17.0 & 14.1 \\
\hline 2002 & 146.6 & 133.0 & 113.5 & 18.9 & 19.4 & 16.8 \\
\hline 2003 & 143.8 & 137.8 & 127.3 & 18.6 & 20.6 & 17.9 \\
\hline 2004 & 141.1 & 144.2 & 130.7 & 16.8 & 17.8 & 15.3 \\
\hline 2005 & 130.4 & 129.3 & 119.2 & 17.0 & 16.7 & 15.7 \\
\hline 2006 & 127.4 & 128.5 & 121.0 & 16.2 & 15.5 & 12.8 \\
\hline 2007 & 125.6 & 116.8 & 99.6 & 16.0 & 17.2 & 15.7 \\
\hline 2008 & 123.8 & 126.7 & 116.6 & 14.8 & 16.1 & 15.5 \\
\hline 2009 & 117.8 & 118.1 & 120.7 & 18.8 & 16.9 & 14.3 \\
\hline Mean & 130.4 & 128.5 & 120.7 & 17.0 & 16.9 & 15.5 \\
\hline
\end{tabular}

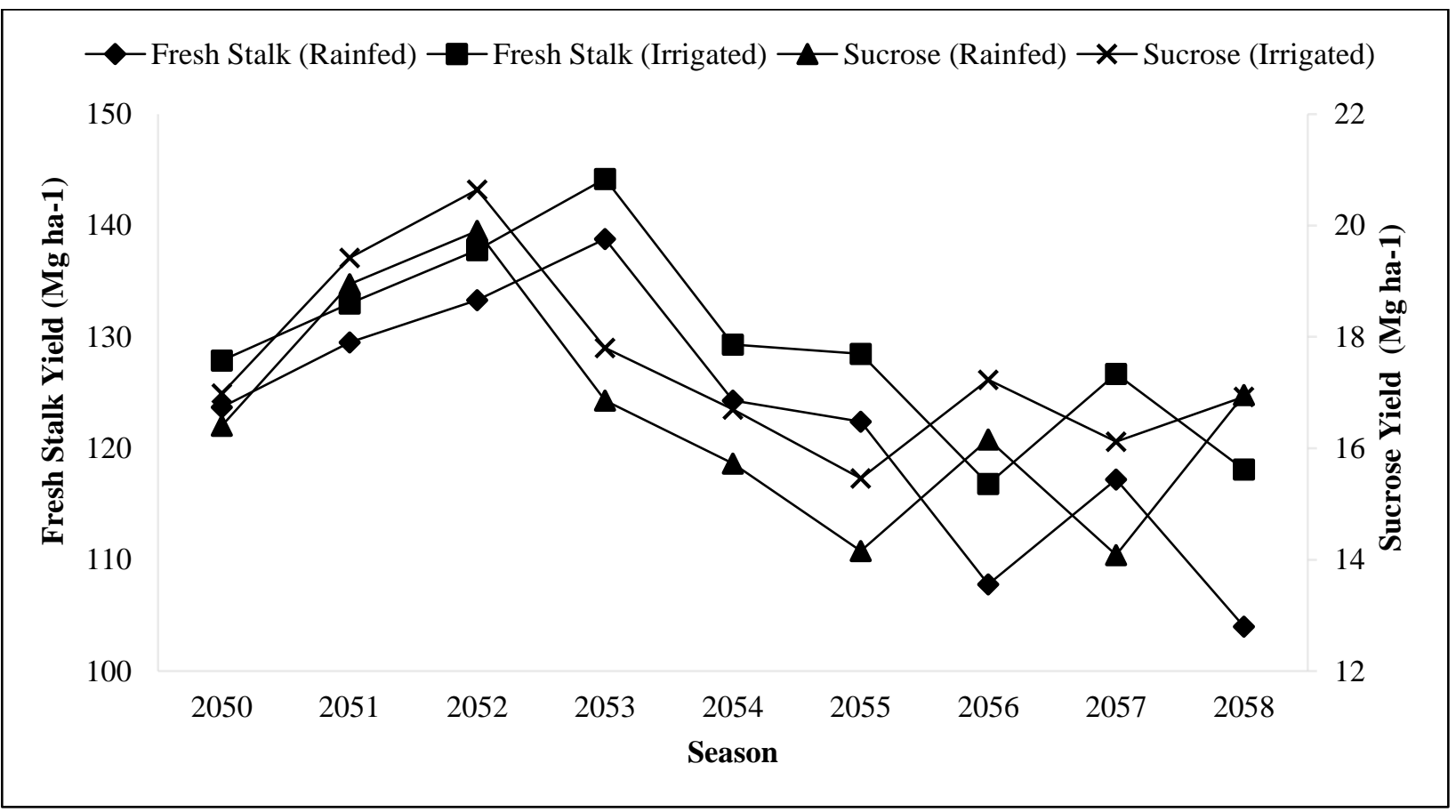

Figure 5. Stems Fresh stalk yield and sucrose yield, under rainfed and irrigated conditions, for the best planting date (Aug. 15), in future scenario B2. Ribeirão Preto, São Paulo State, Brazil. 
The figures presented for future scenarios show that the adoption of an irrigation system can bring quantitative (agricultural yield) and qualitative (sucrose yield) benefits and may have a marked effect in both simulated future scenarios compared to the current scenario.

\section{Water productivity in the rained and irrigated cultivations}

Table 13 expresses water productivity in the crop, the ratio between dry matter yield and evapotranspiration, representing an indicator of water use efficiency in dry matter accumulation. It can be noted that in the simulated scenarios, sugarcane in irrigated cultivation produces more than in the cultivation of rainfed. This can be explained by the elimination of water deficit, enabling maximum transpiration of the crop.

Nevertheless, it is verified that the best use of water occurs in scenario B2 in the condition

of rainfed. In it there was a decrease in the amount of rainfall and an increase of yield per unit of evapotranspiration, with 20.1 and $19.5 \mathrm{~kg} \mathrm{~mm}^{-1}$ for the crops of rainfed and irrigated, respectively. (Figure 6). And this can be explained mainly by the increase in simulated $\mathrm{CO}_{2}$ concentration for the coming years. De Souza et. al. (2008), observed a 30\% increase in photosynthetic rate, $40 \%$ in biomass accumulation and 17\% in the weight of plants grown in a protected environment with a $\mathrm{CO}_{2}$ concentration of $720 \mathrm{ppm}$, a concentration higher than the present day of close to $400 \mathrm{ppm}$. The author explains that it is a result of an increase in $\mathrm{CO}_{2}$ concentration, causing a reduction in stomatal conductance of $37 \%$, reducing transpiration rates, and increasing water use efficiency by $62 \%$.

Therefore, this increase in water use, linked to a lower stomatal opening and low transpiration rate, reflects in a better net photosynthetic performance, given by the subtraction of gross photosynthesis and transpiration plus maintenance respiration, even under a dry period, increasing the internal temperature of the plant, favoring photosynthesis and causing an increase in biomass accumulation, that is, yield (GHANNOUM et al., 2000) (remembering that in the case of $\mathrm{C} 4$ plants, the dynamics of $\mathrm{CO}_{2}$ in mesophilic cells is different from $\mathrm{C} 3$ plants, and photorespiration losses can be disregarded to calculate the net photosynthetic rate (Allen et al., 1985)).

Therefore, the joint effect of the increase in temperature, the increase in $\mathrm{CO}_{2}$ concentration and the best water use efficiency, can increase the production of sugarcane biomass, as found by Morgan et al. (2011) and Marin et al. (2012). 
Table 13. Water productivity of sugarcane crop $\left(\mathrm{PA}, \mathrm{kg} \mathrm{mm}^{-1}\right)$ for current scenarios, B1 e B2. Ribeirão Preto, São Paulo State, Brazil.

\begin{tabular}{ccc}
\hline Scenario & Rainfed & $\left.\mathbf{k g ~ m m}^{-\mathbf{1}} \mathbf{P A}\right]$ \\
& 16.1 & Irrigated \\
\hline Current & 16.8 & 16.8 \\
B1 & 20.1 & 19.6 \\
B2 & 19.5 \\
\hline
\end{tabular}

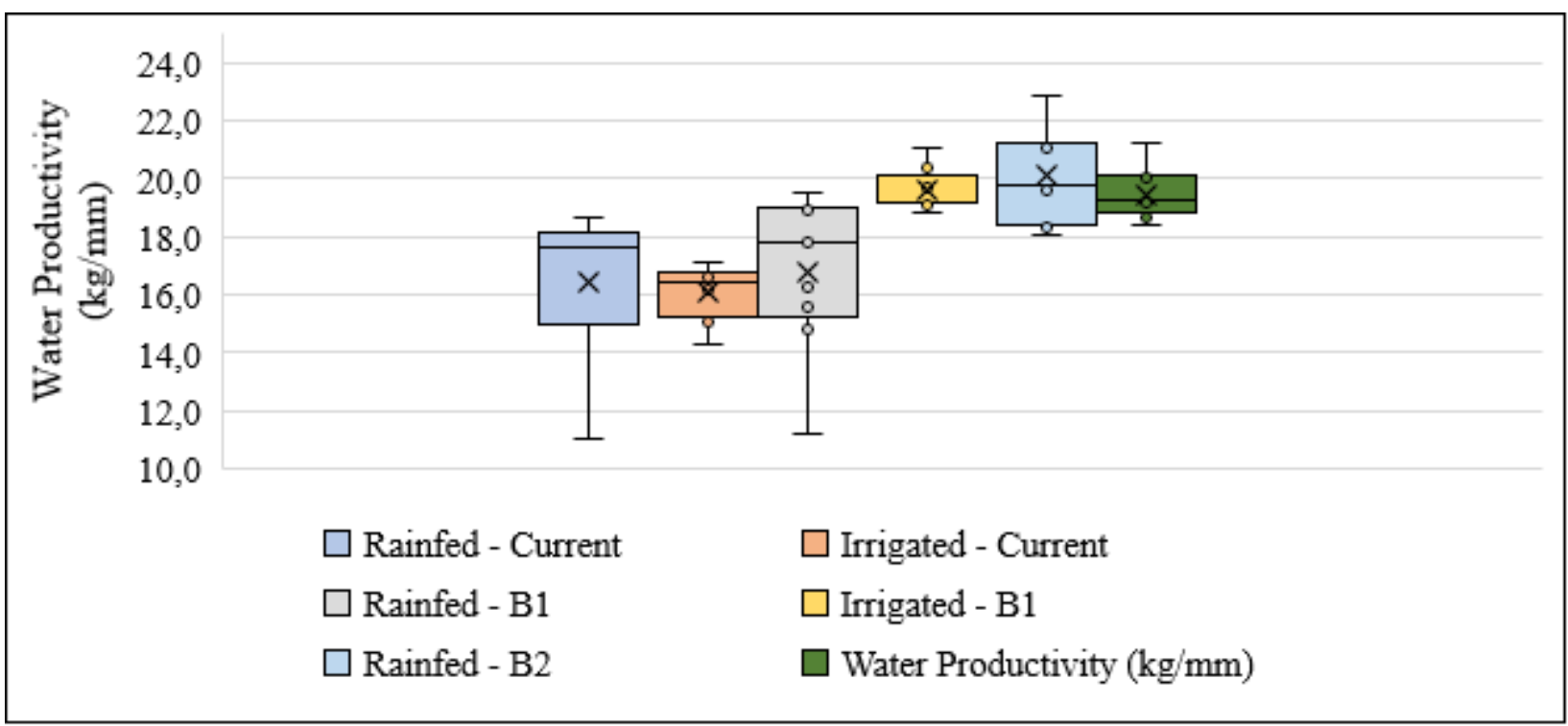

Figure 6. Water productivity $\left(\mathrm{WP}, \mathrm{kg} \mathrm{mm}^{-1}\right.$ ) for current scenarios, B1 e B2. Ribeirão Preto, São Paulo State, Brazil.

\section{Economic viability of the system}

Table 14 shows the results of the economic feasibility study of irrigation.

In the current scenario, IRR was $1.82 \%$, NPV was negative and payback period was fourteen (14) years. Thus, investment in an irrigation system in the Region of Ribeirão Preto would only bring long-term economic return, without any additional investment.

In both future scenarios (B1 and B2), both NPV and IRR resulted in positive values, and payback period was three (03) years. This means that the producer would have net profit from the 4th year after investing in the irrigation system. The profit would be obtained in the short term, so the investment would be recommended for yield gains and profitability. 
Irrigated cultivation also allows to increase the shelf life of sugarcane in the field (reduction of yield losses) and generates the opportunity for the producer to invest in other sectors or processes in its production system, in order to achieve further increases in yield and profitability. In addition, the results of the economic analysis show that the cost to obtain a gain of $1 \mathrm{Mg} \mathrm{ha}^{-1}$ of biomass is $\mathrm{R} \$ 552.77$ in scenario $\mathrm{B} 1$ and $\mathrm{R} \$ 501.54$ in scenario $\mathrm{B} 2$.

Table 14. Economic feasibility study for the proposed system in view of the simulated scenarios. Ribeirão Preto, São Paulo State, Brazil. 2020.

\begin{tabular}{cccc}
\hline Parameters & \multicolumn{3}{c}{ Scenarios } \\
\cline { 2 - 4 } & $\begin{array}{c}\text { Current } \\
\text { (Irrigated) }\end{array}$ & $\begin{array}{c}\text { Future B1 } \\
\text { (Irrigated) }\end{array}$ & $\begin{array}{c}\text { Future B2 } \\
\text { (Irrigated) }\end{array}$ \\
\hline Sugarcane yield $\left(\right.$ ton $\left.^{-1} \mathrm{ha}^{-1}\right)$ & 95.7 & 127.1 & 126.53 \\
Sucrose yield (ton ha & -1 & & 16.5 \\
ATR $\left(\mathrm{kg} \mathrm{ha}^{-1}\right)$ & 12 & 15.9 & 142.6 \\
IRR $(\%)$ & 111.45 & 138.45 & 35.82 \\
NPV (R\$) & $1.84 \%$ & $33.55 \%$ & $\mathrm{R} \$ 152,161,148.91$ \\
Payback period (year) & $-\mathrm{R} \$ 15,730,187.96$ & $\mathrm{R} \$ 139,295,766.10$ & 3 \\
Viability & 14 & 3 & Viable \\
\hline
\end{tabular}

However, based on the assumptions assumed in this study, it was possible to identify a strong sensitivity to the ATR price. In addition, the 15 year service life was used for the irrigation system. Increasing this time to 20 years can reduce the payback of the current scenario. Frizzone et al. (2005), showed that the risk of the irrigation system is associated with its high service life, which makes it difficult to estimate the economic value of the project due to its variations over time.

\section{CONCLUSIONS}

If confirmed, the climate changes simulated in this study will have a positive impact on the agricultural production of sugarcane in rainfed cultivation and in both conditions simulated for rainfall (10\% increase or $10 \%$ reduction).

Irrigation resulted in yield gains of $13 \%$ and $14 \%$ for scenarios B1 and B2, respectively.

Even if the edaphoclimatic conditions simulated in this study favor the cultivation of rainfed sugarcane, irrigation is a viable management option from both points of view, agricultural (increased yield) and economic (increased profitability). 


\section{REFERENCES}

AGUIRRE, L. A. 2000. Introdução à Identificação de Sistemas - Técnicas Lineares e NãoLineares Aplicadas a Sistemas Reais. [S.1.]: Editora UFMG.

ALLEN, L. H.; JONES, P. H.; JONES, J. W. 1985. Rising atmospheric $\mathrm{CO}_{2}$ and evapotranspiration. Advances in evapotranspiration. St. Joseph: ASAE,. P. 13-27.

CONSECANA - Conselho dos Produtores de Cana-de-açúcar, Açúcar, Álcool do Estado de São Paulo, 2006. Manual de instruções CONSECANA. 5.ed. Piracicaba, 111p.

EMBRAPA SOLOS. 2020. Empresa Brasileira de Pesquisa Agropecuária - Embrapa. ISSN Versão 3.104.0. Available at: <https: //www.embrapa.br/solos/sibcs/solos-do-brasil> Accessed on: Mar. 25, 2021.

EPE - EMPRESA DE PESQUISA ENERGÉTICA. 2016. O compromisso do Brasil no Combate às Mudanças Climáticas: Produção e Uso de Energia. Nota Técnica - COP21. Available at: <https://www.epe.gov.br/pt/publicacoes-dados-abertos/publicacoes/nota-tecnica-cop21> Accessed on: Jun. 14, 2021.

FGV - FUNDAÇÃO GETÚLIO VARGAS. 2017. Biocombustíveis. Cadernos FGV. Available at: <https://fgvenergia.fgv.br/publicacao/caderno-de-biocombustiveis> Accessed on: Jun. 14, 2021.

FRIZZONE, J. A.; JÚNIOR, A. S. A.; SOUZA, J. L. M.; ZOCOLER, J. L. 2005. Planejamento de Irrigação: análise de decisão de investimento. Embrapa Informação Tecnológica, Brasília, Distrito Federal, Brasil.

GALINDO, A. M.; CARVALHO, M. E. A. 2016. Comparativo de rentabilidade da produção da cana-de-açúcar em sistema de arrendamento e fornecimento em Chavantes/SP. Revista IPecege, Piracicaba-SP, 2(3), 7-26. Doi: https://doi.org/10.22167/r.ipecege.2016.3.7.

GHANNOUM, O.; VON CAEMMERER, S.; ZISKA, L.H.; CONROY, J.P. 2000. The growth response of $\mathrm{C} 4$ plants to rising atmospheric $\mathrm{CO}_{2}$ partial pressure: a reassessment. Plant, Cell \& Environment, USDA-ARS, Building 046 A,10300 Baltimore Avenue, Beltsville MD 20705, USA, 23,931-942.

HOOGENBOOM, G.; JONES, J. W.; WILKENS, P. W.; PORTE, C. H.; BOOTE, K. J.; HUNT, L. A.; SINGH, U.; LIZASO, J. L.; WHITE, J. W.; URYASEV, O.; OGOSHI, R.; KUO, J.; SHELIA, V.; TSUJI, G. Y. 2014. Decision Support System for Agrotechnology Transfer: version 4.6. University of Hawaii, Honolulu, Hawaii.

INMAN-BAMBER, N.G., 1991. A growth model for sugar-cane based on a simple carbon balance and the CERES-Maize water balance. South African Journal Plant Soil, Pretória, v.8, p.9399. Doi: http://dx.doi.org/10.1080/02571862.1991.10634587

INMAN-BAMBER, N.G.; SMITH, D.M. 2005. Water relations in sugarcane and response to water deficits. Field Crops Research, Amsterdam, v. 92, p. 185-202.

INMAN-BAMBER, N.G.; BONNETT, G.D.; SMITH, D.M.; THORBURN, P.J. 2005. Sugarcane physiology: integrating from cell to crop to advance sugarcane production. Field Crops Research, Australia, v.92, p.115-117.

IAC - INSTITUTO AGRONÔMICO DE CAMPINAS. 2020. Solos do Estado de São Saulo Boletim $200 \quad$ IAC. Available at: <https://www.iac.sp.gov.br/publicacoes/arquivos/iacboletim200.pdf> p. 412-421. Accessed on: Jun. 4, 2021.

JONES, J. W.; HOOGENBOOM, G.; PORTER, C. H.; BOOTE, K. J.; BATCHELOR, W. D.; HUNT, L. A.; WILKENS, P. W.; SINGH, U.; GIJSMAN, A. J.; RITCHIE, J. T. 2003. The DSSAT cropping system model. European Journal of Agronomy, Montpellier, v. 18, n. 3, 
p. $235-265$.

MADHU, M.; HATFIELD, J. L. 2014. Interaction of Carbon Dioxide Enrichment and Soil Moisture on Photosynthesis, Transpiration, and Water Use Efficiency of Soybean. Agricultural Sciences, Ames, USA, v. 5, p. 410-429.

FARIAS, C. H. D.; FERNANDES, P. D.; AZEVEDO, H. M.; DANTAS NETO, J. 2008. Growth indices of irrigated and non-irrigated sugar cane in Paraiba, Brazil. Revista Brasileira de Engenharia Agrícola e Ambiental, Campina Grande, PB, v. 12, n. 4, p. 356-362.

MARIN, F. R.; JONES, J. W.; ROYCE, F.; PELlEGRINO, G. Q.; ASSAD, DELGADO, E.; BARBOSA, F.J. 2012. Climate change impacts on sugarcane attainable yield in southern Brazil. Climatic Change, Piracicaba-SP, p. 1-2.

MARIN, F. R. 2014. Eficiência de produção da cana-de-açúcar brasileira: estado atual e cenários futuros baseados em simulações multimodelos. Tese (Livre Docência em Agrometeorologia) - Escola Superior de Agricultura Luiz de Queiroz, Universidade de São Paulo, Piracicaba, 2014. Doi:10.11606/T.11.2014.tde-22082014-112751. Acesso em: 2021-07-05.

MARIN, F. R. 2016. Understanding sugarcane production, biofuels, and market volatility in Brazil-A research perspective. Outlook on Agriculture, Piracicaba, SP, v. 45, p. 75-77.

MARTINÉ, J-F.; SIBAND, P.; BONHOMME, R. 2003. Simulation of the Maximum Yield of Sugarcane at Different Altitudes: Effect of Temperature on the Conversion of Radiation into Biomass Agronomie, Agronomie 19, Paris, v. 19, p. 3-12.

MORGAN, J. A.; DANIEL, R.; PENDALL, E.; DANA, M.; BLUMENTHAL, B.; KIMBALA, A.; YOLIMA, C. 2011. C4 Grasse Prosper as Carbon Dioxide Eliminates Desiccation Warmed Semi-Arid Grassland, Nature, London, v.476, p. 202-205.

NASSIF, D. S. P.; MARIN, F. R.; COSTA, L. G. 2013. Evapotranspiration and Transpiration Coupling to the Atmosphere of Sugarcane in Southern Brazil: Scaling Up from Leaf to Fiel. Sugar Tech, Piracicaba, SP, vol. 3, p. 1-5.

OLIVEIRA, E. C. A.; FREIRE, F. J.; OlIVEIRA, A. C.; NETO, D. E. S.; ROCHA, A. T.; CARVALHO, L. A. 2011. Produtividade, eficiência de uso da água e qualidade tecnológica de cana-de-açúcar submetida a diferentes regimes hídricos. Revista Pesquisa Agropecuária Brasileira, Brasília, v. 46, n. 6, p. 617-625.

PAGANI, V.; STELLA, T.; GUARNERI, T.; FINOTO, G.,;VAN DEN BERG, M.; MARIN, F. R.; ACUTIS, M.; CONFALONIERI, R. 2017. Forecasting sugarcane yields using agroclimatic indicators and Canegro model: A case study in the main production region in Brazil. Agricultural Systems, Milano, Italy, v. 154, n. November 2016, p. 45-52.

RAMESH, P. 2000. Effect of different levels of drought during the formative phase on growth parameters and its relationship with dry matter accumulation in sugarcane. Journal Agronomy and Crop Science, Berlin, v.185, p.83-89.

ROBERTSON, M.J.; MUCHOW, R.C.; DONALDSON, R.A.; INMAN-BAMBER, N.G.; WOOD, A.W. 1999. Estimating the risk associated with drying-off strategies for irrigated sugarcane before harvest. Australian Journal of Agricultural Research, v.50, p.65-77.

SAGE, R.F. 2002. Variation in the k(cat) of Rubisco in C3 and C4 plants and some implications for photosynthetic performance at high and low temperature. Journal of experimental botany. Toronto, CA, vol. 53, p. 609-620.

SILVA, A.L.C.; COSTA, W.A.J.M. 2004. Varietal variation in growth, physiology and yield of sugarcane under two contrasting water regimes. Tropical Agricultural Research, Peradeniya, Sri Lanka, v.16, p.1-12.

SILVA, M.A.; ARANTES, M.T.; RHEIN, A.F.L.; GAVA, G.J.C.; KOLLN, O.T.2014. Potencial 
produtivo da cana-de-açúcar sob irrigação por gotejamento em função de variedades e ciclos.

Revista Brasileira de Engenharia Agrícola e Ambiental, v. 18, n. 3, p. 241-249.

SINGELS, A.; JONES, M.; MARIN, F.R.; RUANE, A.; THORBURN, P. 2013. Predicting Climate Change Impacts on Sugarcane Production at Sites in Australia, Brazil and South Africa Using the Canegro Model. Sugar Tech, vol. 16, n. 4, p.347-355. Doi: 10.1007/s12355-013-0274-1.

SINGELS, A.; JONES, M.; VAN DEN BERG, M. 2008. DSSAT v4. 5-Canegro Sugarcane Plant Module. International Consortium for Sugarcane Modelling (ICSM).

SINGELS, A.; JONES, M.; VAN DER BERG, M. 2008. DSSAT v.4.5 DSSAT/CANEGRO Sugarcane Plant Module. Scientific Documentation. International Consortium for sugarcane Modeling. South African Sugarcane Research Institute, Mount Edgecombe, South Africa, 34p.

SINGELS, A.; BEZUIDENHOUT, C.N. 2002. A New Method of Simulating Dry Matter Partitioning in the Canegro Sugarcane Model. Field Crops Research, Amsterdan, v.78 151164 p. Doi: http://dx.doi.org/10.1016/S0378-4290(02)00118-1.

SINGH, P.N.; SHUKLA, S.K.; BHATNAGAR, V.K. 2007. Optimizing soil moisture regime to increase water use efficiency of sugarcane (Saccharum spp. Hybrid complex) in subtropical India. Agricultural Water Management, v.90, p.95-100.

SOUZA, A. P.; GASPAR, M.; DA SILVA, E. A.; ULIAN, E. C.; WACLAWOVSKY, A. J.; NISHIYAMA JR., M. Y.; DOS SANTOS, R. V.; TEIXEIRA, M. M.; SOUZA, G. M.; BUCKERIDGE, M. S. 2008. Elevated $\mathrm{CO}_{2}$ increases photosynthesis, biomass and productivity, and modifies gene expression in sugarcane. Plant, Cell and Environment, v. 31, n. 8, p. 1116-1127.

SOUZA, D. M. G.; LOBATO, E. 2013. Terra Roxa Estruturada/Nitossolo Vermelho. Available at: <agencia.cnptia.embrapa.br/Agencia16/AG01/arvore/AG01_98_10112005101957.html> Accessed on: Mar. 31, 2020.

STOKES, C. J.; INMAN-BAMBER, N. G.; EVERINGHAM, Y. L.; SEXTON, J. 2016. Measuring and modelling $\mathrm{CO}_{2}$ effects on sugarcane. Environmental modelling \& software. Vol. 78: p. 68-78.

TAKEI, K.; TAKAHASHI, T.; SUGIYAMA, T.; YAMAYA, T.; SAKAKIBARA, H. 2002. Multiple routes communicating nitrogen availability from roots to shoots: a signal transduction pathway mediated by cytokinin. Journal of Experimental Botany, Japan, v.53, n. 370, p. 971-977.

TRENBERTH, K E; JONES, P D; AMBENJE, P; BOJARIU, R; EASTERLING, D; KLEIN TANK, A; PARKER, D; RAHIMZADEH, F; RENWICK, J A; RUSTICUCCI, M; SODEN, B; ZHAI, P. 2007. Observations. Surface and Atmospheric Climate Change. Chapter 3. IPCC Working Group I, National Oceanic and Atmospheric Administration NOAA. DSRC R/AL/8, 325 Broadway, Boulder, CO 80305 (United States), p. 236-336.

VOLPE, V.; MANZONI, S.; MARANI, M.; KATUL, G. 2011. Leaf conductance and carbon gain under salt-stressed conditions. Journal of Geophysical Res; 116, Doi: 10.1029/JG001848.

VU, J. C. V.; ALLEN, JR. L. H. 2009. Growth at elevated CO2 delays the adverse effects of drought stress on leaf photosynthesis of the C4 sugarcane. Journal of Plant Physiology, University of Florida, Gainesville, FL 32611-0500, USA, vol. 166, n. 2, p.107-116. 